\title{
The Distribution and Cost of Library Service
}

W

HAT PROPORTIONS of personnel expenditures and staff are allocated to cataloging, acquisitions, circulation, reference, departmental libraries, special collections? It is an unusual librarian who knows the answer to this question. It is generally assumed that the staff is distributed in such a way that library service is integrated adequately with the teaching, research, and extension programs of the university. The achievement of this basic objective of university libraries depends largely upon the adequacy and the quality of the staff as well as the way in which materials are organized; the organization of materials determines to a great extent the organization of staff and distribution of salaries and wages. An analysis of this distribution will give not only a better understanding of library service, but also some indication of the extent to which the basic objectives of the library are being achieved. There is need for a valid comparative study of the distribution of staff and personnel budgets among departments and functions of a large number of libraries. Such a study would be useful to individual libraries in long-range personnel budget planning and in pointing to staff needs, strengths, and weaknesses. It may also suggest more efficient distribution and use of staff.

There is another important reason why there is need for an understanding of the use of salaries and wages. The largest proportion of the annual budgets of university libraries is expended, not for books, but for library service and for the organization and acquisition of materials in the form of salaries and wages. This

Mr. Littleton is assistant to the librarian, University of North Carolina. is true for each of the 107 Class I libraries in the ACRL statistical compilation for 1954-55. ${ }^{1}$ One hundred and five libraries spent over half of their total income on staffing. This information has special significance at the present time because of the recently increased concern about the financial problems of libraries.

The participants at the Monticello Conference of the Association of Research Libraries held in October, 1954, recognized the need for comparative studies. President Morey, of the University of Illinois, "expressed the opinion that valid comparisons are extremely difficult, yet that such comparisons are almost the only way to judge whether or not a cost is reasonable." 2 Williams in the volume that summarizes the conference says, "Information is lacking at present on many aspects of library costs as a whole. ... Universities and their libraries do a number of different things at once, and no one it appears, knows how much of the total expenditures goes into each function." 3

The main reason that such information is lacking is the difficulty of obtaining valid comparisons. The same operations are performed to some degree in most university libraries, but they are not performed in the same departments or in the same way in all libraries. It is also difficult to ascertain costs of functions which are distributed over several departments, such as reference service or cataloging. Therefore, a strict comparison by departments would have little meaning. However, for some functions, such as reference service, it is impossible to extract

\footnotetext{
1 Dale M. Bentz, "College and University Library 1 Dale M. Bentz, "College and Uni
Statistics," CRL, XVII (1956), 58-59.

${ }_{2}$ Edwin E. Williams, Problems and Prospects of the Research Library (New Brunswick, N. J.: The Scarecrow Press, 1955), p. 38. Ibid., p. 12.
} 
the function from other duties of a department, and a comparison of departmental costs is, in many cases, the only solution.

\section{Description of the Study}

The lack of detailed comparative data became apparent when an analysis of the use of staff and personnel expenditures at the University of North Carolina Library was made. It was impossible to determine if the expenditures and staff for functions and departments were reasonable since there were no data from other libraries with which to compare them. As a result, it was decided to attempt an exploratory investigation of the distribution of staff and salaries and wages in a small sample of libraries. A letter was written to the librarians of 30 libraries with collections of more than 500,000 volumes asking if they would participate in such a study. Sixteen libraries furnished data. Each library was asked to submit the following for the fiscal year 1954-55: (1) the number of staff members, broken down by professional and nonprofessional, in each department and (2) the amount of salaries and wages allocated to separate departments. The librarians were instructed to submit data separately for operations not representative of the major function of the department in which they were performed. For instance, if the mending and repair unit was administered under the circulation department it was reported separately and not as a part of the totals for the circulation department. The departments were grouped under six main divisions: general administration, public services, technical services, special collections, special and miscellaneous services, and special and departmental libraries. The definitions of each of these categories for the purposes of this study are as follows:

General Administration includes the chief librarian, associate and assistant librarians, administrative assistants, secretaries, typists attached to the director's or librarian's office. It includes only those who participate in general administration and does not include persons who do specialized jobs, such as photoduplication or interlibrary loans.

Public Services refers to general lending and reference services, including the reference, circulation, and documents departments, undergraduate, graduate, reserve, and divisional reading rooms. It includes interlibrary loans, but not extension service.

Technical Services embraces the departments of acquisitions, order, serials, cataloging, and mending and repair. "Cataloging" includes all persons who do complete cataloging of books and serials regardless of the department in which they work, but not manuscript processing or public documents check-listing. Serials catalogers are included under "Cataloging" even if they work in the serials department.

Special Collections includes separate collections of special materials, such as manuscripts, maps, newspapers, rare books, prints, and state, university or archive collections.

Special and Miscellaneous Services includes the following departments: extension, photoduplication, mailing and shipping, and rental collections.

Special and Departmental Libraries: Data for each special or departmental library staffed with full or part-time personnel who devote their time exclusively to the library are included. Departmental secretaries in charge of libraries as a part of their duties are not listed.

The 16 libraries in the sample range in size from 2,696,862 to 552,171 volumes and have a regional distribution as follows: Midwest, 5; Far West, 4; East, 1; and South, 6. The libraries were careful to report data within the limits of the definitions. Therefore, the data, especially for the broad divisions, have high validity and comparability.

In Table 1, the proportion of total salaries and wages and of staff assigned to the six major divisions as well as cataloging and acquisitions for each of the 16 libraries may be seen. The libraries are 
TABLE 1

PERCENTAGES OF SALARIES AND WAGES AND OF FULL-TIME STAFF ALLOCATED TO EIGHT DIVISIONS IN 16 UNIVERSITY LIBRARIES, 1954-55

\begin{tabular}{|c|c|c|c|c|c|c|c|c|c|c|c|c|c|c|c|c|}
\hline \multirow[t]{2}{*}{ LIBRARY } & \multicolumn{2}{|c|}{ ADMINISTRATION } & \multicolumn{2}{|c|}{ ACQUisitions } & \multicolumn{2}{|c|}{ Cataloging } & \multicolumn{2}{|c|}{$\begin{array}{c}\text { TOT. TECHNICAL } \\
\text { SERVICES }\end{array}$} & \multicolumn{2}{|c|}{$\begin{array}{l}\text { Public } \\
\text { Services }\end{array}$} & \multicolumn{2}{|c|}{$\begin{array}{c}\text { SPECIAL } \\
\text { LiBRARIES }\end{array}$} & \multicolumn{2}{|c|}{$\begin{array}{c}\text { SPECIAL } \\
\text { Collections }\end{array}$} & \multicolumn{2}{|c|}{$\begin{array}{l}\text { SPECIAL } \\
\text { SERVICES }\end{array}$} \\
\hline & $\begin{array}{l}\text { Salaries } \\
\text { o Wages }\end{array}$ & Staff & $\begin{array}{l}\text { Salaries } \\
\text { \& Wages }\end{array}$ & Staff & $\begin{array}{l}\text { Salaries } \\
\text { \& Wages }\end{array}$ & Staff & $\begin{array}{l}\text { Salaries } \\
\text { \& Wages }\end{array}$ & Staff & $\begin{array}{l}\text { Salaries } \\
\text { Wages }\end{array}$ & Staff & $\begin{array}{l}\text { Salaries } \\
\text { \& Wages }\end{array}$ & Staff & $\begin{array}{l}\text { Salaries } \\
\& \text { Wages }\end{array}$ & Staff & $\begin{array}{l}\text { Salaries } \\
\text { o Wages }\end{array}$ & Staff \\
\hline A & 6.7 & 3.9 & 18.1 & 22.4 & 21.5 & 24.0 & 41.0 & 47.8 & 20.0 & 19.9 & 25.9 & 22.3 & 2.7 & 2.0 & 3.7 & 4.1 \\
\hline $\mathbf{B}^{\mathbf{1}}$ & 4.6 & 4.3 & 7.7 & 10.3 & 16.3 & 18.6 & 26.7 & 32.8 & 15.6 & 16.6 & 46.1 & 41.5 & 4.2 & 2.4 & 2.8 & 2.4 \\
\hline C & 10.1 & 7.0 & 10.8 & 12.9 & 24.5 & 27.5 & 36.6 & 42.7 & 27.8 & 24.6 & 16.7 & 15.2 & 6.4 & 8.2 & 2.3 & 2.3 \\
\hline D & 9.9 & 5.9 & 19.8 & 21.3 & 18.8 & 18.9 & 39.5 & 41.4 & 20.0 & 21.3 & 24.0 & 26.1 & 4.2 & 4.1 & 2.4 & 1.2 \\
\hline $\mathbf{E}$ & 5.5 & 4.25 & 18.5 & 18.2 & 21.6 & 25.4 & 40.8 & 44.25 & 25.6 & 22.4 & 19.6 & 20.6 & 4.7 & 4.25 & 3.8 & 4.25 \\
\hline $\mathbf{F}$ & 5.6 & 4.4 & 16.5 & 20.4 & 16.7 & 17.6 & 35.2 & 40.9 & 28.0 & 23.4 & 17.3 & 18.1 & 11.6 & 10.2 & 2.3 & 2.9 \\
\hline G & 9.4 & $6.5^{\circ}$ & 12.5 & 15.7 & 21.7 & 24.2 & 36.1 & 42.5 & 29.5 & 27.4 & 20.5 & 18.3 & 2.1 & 2.1 & 2.4 & 3.3 \\
\hline $\mathbf{H}$ & 8.0 & 4.2 & 16.1 & 16.67 & 28.8 & 33.33 & 44.9 & 50.0 & 20.1 & 18.75 & 26.4 & 25.0 & .6 & 2.08 & .. & .. \\
\hline I & 11.2 & 7.0 & 19.7 & 25.6 & 8.9 & 11.6 & 28.6 & 37.2 & 33.0 & 25.6 & 24.7 & 27.9 & 2.5 & 2.3 & .. & . \\
\hline J & 4.5 & 3.0 & 16.6 & 17.7 & 19.5 & 14.5 & 37.6 & 44.2 & 27.8 & 22.5 & 26.6 & 27.7 & .. & .. & 3.5 & 2.6 \\
\hline $\mathrm{K}$ & 9.5 & 6.7 & 11.4 & 12.1 & 17.9 & 21.5 & 30.3 & 34.9 & 22.6 & 22.1 & 13.7 & 12.8 & 13.8 & 13.4 & 9.1 & 10.0 \\
\hline L & 9.6 & 5.8 & 16.7 & 20.4 & 21.5 & 21.3 & 38.2 & 41.7 & 28.8 & 24.3 & 15.6 & 16.5 & 6.2 & 9.7 & 1.5 & 1.9 \\
\hline $\mathbf{M}$ & 5.8 & 4.1 & 13.4 & 16.4 & 19.1 & 22.1 & 34.9 & 40.6 & 27.5 & 23.5 & 26.9 & 23.4 & 2.9 & 2.8 & 1.9 & 5.6 \\
\hline $\mathrm{N}$ & 10.4 & 7.8 & 19.6 & 23.3 & 21.8 & 24.5 & 45.7 & 54.1 & 24.7 & 20.2 & 12.6 & 10.9 & 5.8 & 5.4 & .8 & 1.6 \\
\hline 0 & 5.6 & 3.8 & 9.1 & 13.1 & 13.6 & 24.2 & 24.8 & 31.4 & 24.2 & 21.6 & 43.7 & 41.3 & .. & .. & 1.7 & 1.9 \\
\hline $\mathbf{P}$ & 7.4 & 4.4 & 15.5 & 17.6 & 19.4 & 22.5 & 36.1 & 41.8 & 39.5 & 37.9 & 6.5 & 6.2 & 4.0 & 3.5 & 6.5 & 6.2 \\
\hline Mean & 7.7 & 5.2 & 15.1 & 17.75 & 19.5 & 21.98 & 36.1 & 41.76 & 25.9 & 23.25 & 22.9 & 22.1 & 5.1 & 5.2 & 3.2 & 3.6 \\
\hline Median & 7.05 & 4.35 & 16.3 & 17.17 & 19.25 & 22.3 & 36.25 & 41.75 & 26.2 & 22.45 & 22.25 & 21.4 & 4.1 & 3.8 & 2.3 & 2.75 \\
\hline High & 11.2 & 7.8 & 19.8 & 25.6 & 28.8 & 33.33 & 45.7 & 54.1 & 39.5 & 37.9 & 46.1 & 41.5 & 13.8 & 13.4 & 9.1 & 10.0 \\
\hline Low & 4.5 & 3.0 & 7.7 & 10.3 & 8.9 & 11.6 & 24.8 & 31.4 & 15.6 & 16.6 & 6.5 & 6.2 & .6 & 2.0 & .8 & 1.2 \\
\hline Number of Libraries & 16 & 16 & 16 & 16 & 16 & 16 & 16 & 16 & 16 & 16 & 16 & 16 & 14 & 14 & 14 & 14 \\
\hline
\end{tabular}

${ }^{1}$ Data do not include the director and assistant director of libraries. 
arranged by size, the largest library first. "Acquisitions" includes all persons who participate in book and serials cataloging regardless of the department in which it is performed.

\section{The Use of the Data by an}

Individual Library

The variations in the distribution of salaries and wages and of staff among libraries is to be expected because of the differences in the sizes and interests of student bodies and faculties, in organizational structure, in the sizes of campuses, in the traditions of institutions which tend to emphasize certain collections and departments, and many other variables. However, by studying these individual differences we can gain a better understanding of the strengths and weaknesses of a particular library.

For example, let us examine the profile of one of the libraries. Library $\mathrm{K}$ ranks thirteenth in the percentage of total salaries and wages and staff allocated to acquisitions, twelfth in the percentage allocated both to cataloging and public services, and near the bottom for the proportion spent on special and professional libraries. On the other hand, in the percentage allocated to special collections and special services, it ranks first. This information, along with the comparative data on the actual number of employees, the actual expenditures for each department, and data on library size and total book budget can be used to determine where new positions need to be added. It can also be used to strengthen arguments for additional positions when presenting requests to university officials and the state budget bureau. Since the special collections and special services which draw such a high percentage of both staff and salaries and wages are heavily used, distinguished, and well established, support cannot be withdrawn from them, but with these data, the librarian can explain why his budget request is as large as it is. The staffing problem in this library is not so much in the total numbers of personnel as in a critical understaffing in general library services, public service and bibliographical processing.

A comparative analysis can also reveal weaknesses in internal organization. Transfers of operations from understaffed departments to departments more adequately staffed may result and weaknesses in departmental routines can be spotted.

An analysis of each of the other libraries will show different patterns of staff distribution. Each should benefit from a comparative analysis of its organization.

\section{Further Statistical Analysis}

By means of correlation technique, the data can be compared with many variables to determine if there is any relationship between a particular factor and the organization and cost of staff. Some of the data that may be correlated with these are library use statistics, volumes added, total number of volumes, student enrollment, size of faculty, the number of academic departments, and graduate and undergraduate degrees offered or conferred. Time has not permitted such a thoroughgoing analysis, but actual salaries and wages and the percentage allocated to each division were correlated with total number of volumes, student enrollment, number of special libraries and total salaries and wages by means of the Spearman R ho correlation formula. The coefficients obtained are not presented here since the sample is so small. Clear-cut patterns and trends were indicated by them, however. Some generalizations about the cost and distribution of library service can be made, but they are presented more as hypotheses than as conclusive findings. Many of the findings substantiate general assumptions held for many years.

\section{The Nature of University Library Service and Its Cost}

As a library grows in size its personnel budget and its staff grow also. This generally confirmed assumption was proven 
statistically. In the sample there is a positive correlation between library size and the total personnel budget and staff, but it is not a perfect correlation because some of the smaller libraries have personnel budgets higher than libraries of greater size. These smaller libraries are growing faster and have a greater number of service units. Library $M$ is thirteenth in size, but ranks fifth in total salaries and wages and second in the number of volumes added. This library also has three divisional reading rooms and an undergraduate library as well as a large group of departmental libraries. If the sample were larger, a study might be made of the staffs of libraries of comparable number of volumes.

Not only does the total personnel expenditure of a library increase as it grows in size, but the costs of the various services increase also. However, all do not increase at the same rate. A smaller share goes into the staffing of public services and a larger share into an ever-increasing number of special and professional libraries. Correlations between size and actual expenditures for each of the divisions listed in Table $I$ were high and positive; but those between size and the percentage expended on administration and public services were negative; and those between size and the proportion spent on special libraries positive and moderately high. "The larger a campus grows and the larger the library grows, the greater is the inclination to split off portions from the central collection and transport them to locations more convenient for the principal users thereof. Beyond a certain large size there is a desire on the part of users to flee from the large general services like loan desks and reference departments - operating in monumental Greco-Roman halls-to press for creation of smaller and cozier quarters and less impersonal service. This is good but it certainly costs money."4

-Williams, op. cit., p. 130.
This keen observation by Coney at the Monticello Conference was substantiated by this study. As research strength increases, not only are more special libraries established, but they must be staffed with more highly qualified personnel. Many of the medium size libraries (between 500,000 and $1,000,000$ volumes) have several departmental libraries which are staffed on a part-time basis by departmental secretaries, or not staffed at all, but the larger libraries and those that serve the larger universities have numerous departmental collections staffed with library personnel who usually have some knowledge of the subject.

Size of library is not the only factor, perhaps not even the most important one that influences the splitting off of portions from the general collection. Some of the other factors that affect this relationship between general public service and departmental library service are: the research strength of the collection, the size of the student body, the number and types of professional schools and academic departments offering graduate degrees and the arrangement of the library building. Universities with the largest enrollments have usually developed more professional schools and graduate departments. As this type of organization evolves, a larger percentage of the total personnel budgets go into staffing specialized and professional school libraries, a smaller percentage into general public services. When the total number of students was correlated with the percentage of the total salaries and wages allocated to public services, a very significant negative coefficient $(-.94)$ was obtained. The correlation between the total number of students and the percentage of personnel costs allocated to special and departmental libraries was also very significant, but positive. There were high positive correlations between the total number of special libraries staffed and the total number of students (.96), whereas only a moderate correlation was obtained when the 
size of the library was correlated with the total number of special and departmental libraries. These data substantiate the theory that the development of a strong departmental library system depends more on the size of the student enrollment, which to some extent reflects the number of professional schools and academic departments, than upon the size of the library. However, size in volumes is also a factor in these costs.

Another indication of the importance of student enrollment on the development of special libraries is derived from a comparison of the average percentages allocated to public services and to special libraries in institutions of over 10,000 students and in those with enrollments under 10,000 . The average percentage allocated to public services in institutions with student enrollments of over 10,000 is 22.1 , whereas 31.4 per cent is allocated to special and departmental libraries. In institutions with enrollments under 10,000 this ratio is reversed; public service costs amount to 28.9 per cent and special and departmental library costs average 17.1 per cent.

The most frequent special libraries in the sample are those that serve professional schools. Fourteen of the institutions have engineering libraries, 13 have law libraries, and 11 have medical libraries. Two of the medical libraries are administered separately and data for them are not reported. A large number of collections devoted to the sciences, especially in the fields of chemistry, geology, physics and mathematics, have developed in the institutions offering extensive graduate training in these fields. Twelve of the libraries maintain separate chemistry collections, ten have geology libraries and nine have mathematics and physics collections. Other fields for which special libraries have developed frequently are fine arts-especially art, architecture, and music_business administration, industrial relations, and education. Separate collections have developed less frequent- ly in the social sciences and humanities.

The most costly special libraries are those devoted to medicine and law because they are usually larger, must be staffed by personnel with specialized training, and demand long hours of opening. The average percentages of total salaries and wages allocated to these li-

\section{TABLE 2}

MEANS, MEDIANS, AND RANGE OF PERCENTAGES OF TOTAL SALARIES AND

WAGES ALLOCATED TO LAW, MEDICAL AND ENGINEERING LIBRARIES IN 16 UNIVERSITIES, 1954-55

\begin{tabular}{l|c|c|c}
\hline \hline & Law & Medicine & Engineering \\
\cline { 2 - 3 } Mean & 5.2 & 5.0 & 2.5 \\
Median & 4.8 & 4.3 & 2.55 \\
High & 11.2 & 11.1 & 6.5 \\
Low & 2.2 & 2.1 & .9 \\
Number & & & \\
of Libraries & 13 & 9 & 14 \\
\hline
\end{tabular}

braries as compared to those of engineering libraries are given in Table 2. A comparative study of the staffing of libraries in the various fields would be a worthwhile separate project.

Although the actual amount spent on administrative personnel increases as a library grows in size, the percentage of the salaries and wages allocated to general administration tends to be lower in larger libraries and in those with higher total personnel expenditures.

Approximately one-fourth of the total salaries of these 16 libraries was expended for public services. Table 3 gives the average percentages spent on selected public service departments. All 16 libraries maintain central circulation departments, even those which have divisional reading rooms. The proportion allocated to circulation is less variable than that for any other department. Most of the libraries spend from 8 to 10 per cent on circulation department regardless of the number of service units, the size of the library or the size of the total personnel budget. All li- 
TABLE 3

MEANS, MEDIANS, AND RANGE OF PERCENTAGES OF TOTAL SALARIES AND WAGES AND STAFF ALLOCATED TO SELECTED PUBLIC SERVICE UNITS IN 16 UNIVERSITY LIBRARIES, 1954-55

\begin{tabular}{|c|c|c|c|c|c|c|c|c|c|c|}
\hline & \multicolumn{2}{|c|}{ Circulation } & \multicolumn{2}{|c|}{ Documents } & \multicolumn{2}{|c|}{ REFERENCE } & \multicolumn{2}{|c|}{$\begin{array}{l}\text { UNDERGRADUATE } \\
\text { READING ROOMS }\end{array}$} & \multicolumn{2}{|c|}{$\begin{array}{c}\text { Divisional } \\
\text { READING RoOMs }\end{array}$} \\
\hline & $\begin{array}{l}\text { Salaries } \\
\text { \& Wages }\end{array}$ & Staff & $\begin{array}{l}\text { Salaries } \\
\text { \& Wages }\end{array}$ & Staff & $\begin{array}{l}\text { Salaries } \\
\text { d Wages }\end{array}$ & Staff & $\begin{array}{l}\text { Salaries } \\
\text { \& Wages }\end{array}$ & Staff & $\begin{array}{l}\text { Salaries } \\
\text { \& Wages }\end{array}$ & Staff \\
\hline Mean & 9.4 & 7.6 & 2.7 & 2.8 & 6.5 & 5.98 & 3.7 & 3.2 & 3.5 & 3.2 \\
\hline Median & 8.9 & 7.3 & 2.35 & 2.25 & 6.5 & 5.95 & 3.0 & 1.6 & 3.6 & 3.1 \\
\hline High & 12.1 & 10.3 & 4.1 & 4.7 & 10.9 & 11.1 & 9.5 & 9.3 & 6.0 & 7.1 \\
\hline Low & 7.2 & 5.9 & 1.6 & 1.6 & 2.5 & 2.08 & 1.5 & 1.0 & 1.9 & 1.7 \\
\hline $\mathrm{N}^{1}$ & 15 & 15 & 10 & 10 & 16 & 16 & 7 & 7 & 9 & 9 \\
\hline
\end{tabular}

${ }^{1} \mathrm{~N}$ equals the number of units. In the case of all except divisional reading rooms it refers to the number of libraries on which the percentages are based. In the case of divisional reading rooms it refers to nine in four different libraries.

braries in the sample maintain central reference departments also, but the percentage allocated to centralized reference varies considerably. In some libraries, most of the reference service is concentrated in one department. In others, it is distributed among a number of departments or separate divisional reading rooms. In systems which have developed strong departmental libraries, much of the reference service has been transferred to these libraries. The development of general open-shelf collections for the undergraduate in the form of undergraduate libraries and reading rooms and divisional reading rooms reflects a need for undergraduates to have free access to a limited collection of representative books on all subjects and the recent trend of organizing libraries for more effective use by the undergraduate. Seven of the libraries have undergraduate reading rooms or libraries and four have divisional reading rooms. In only one case has a library developed both. The larger research libraries in this sample (over 1,000,000 volumes) do not maintain divisional reading rooms, but they do maintain strong undergraduate collections in separate reading rooms. Wilson and Tau- ber in The University Library ${ }^{5}$ point to several university libraries with divisional plans. Two of those mentioned contain over $1,000,000$ volumes. This may be due in part to the arrangement of the buildings in which they are housed; it may indicate that divisional organization is impractical for large university libraries; or there may be other reasons why they do not have divisional organization. The scarcity of large university libraries with divisional organizations does disprove that it is feasible or educationally advantageous. However, there is need for research in order to answer the questions: "What kinds of libraries should have divisional organization?"'

Only two libraries in the sample have full-scale divisional plans, with humanities, science, and social science reading rooms. The library ranking sixteenth in size, with 550,000 volumes, spends 39.5 per cent of its personnel budget on public services, 16.6 per cent for divisional libraries. This library, which has a relatively small graduate enrollment, has few departmental libraries. The other library

\footnotetext{
5 Louis R. Wilson and Maurice F. Tauber. The University Library (2d ed., New York: Columbia University Press, 1956), 146-47.

Ibid., p. 592.
} 
with a full-scale divisional plan ranks thirteenth in size, but fifth in total salaries and wages. It is spending 7.9 per cent of its budget on divisional libraries in addition to an undergraduate library, traditional public service departments of circulation and reference as well as a large number of departmental libraries. This university's enrollment is approaching 10,000 with a relatively large graduate enrollment, which explains the need for the heavy expenditure for departmental libraries in addition to a large outlay for undergraduate services. Unfortunately, there are not enough divisional libraries in this sample to give a conclusive answer to Downs' question: "Are subjectdivisional types of library organizations more expensive to administer than traditional forms?" "However, the percentage of total personnel budgets allocated to divisional libraries may be compared with that of the traditional units in Table 3. In the libraries in this sample divisional libraries are maintained side by side with the traditional units of reference and circulation. There seems to be little difference between the cost of circulation and reference departments in libraries with divisional collections and the cost of the same departments in libraries without the added divisional collections.

The libraries in this sample spent a little more than one-third of their total salaries and wages and use about 40 per cent of their staffs in acquiring and organizing materials for collections. Slightly more is usually spent on cataloging than for the processes of bibliographic checking and acquisitions. An average of 15 per cent of the total salaries and wages is allocated to acquisitions and about 20 per cent for cataloging. There is only a moderate positive correlation between cataloging salary costs, the size of the library, and the number of special and professional libraries. These costs evidently

TRobert B. Downs, "Introduction," Library Trends, I (1952), 12 . vary among libraries because of other factors such as cataloging policies and routines.

Salaries and wages allocated to special collections and special services make up a small percentage of the total personnel budgets of most libraries. One factor in the cost of staffing special collections may be their place in the organizational structure of the library. Horn has recently noted a trend toward coordinating special collections under one department head. ${ }^{8}$ In the sample here under study, six libraries have departments of special collections. At the two universities which rank first and second in the percentage spent on special collections, large manuscripts and rare book departments are administered separately. At one of these, a strong state collection is included in this category. These collections have had a long and distinguished development and are now strongly established traditions of the two campuses; indeed they add significantly to the research strength of the libraries of which they are a part.

A factor in the high special service costs of the highest ranking library in this category is an old and established extension department which offers heavily used lending and reference services to the citizens of the state. It has grown over the years because of the lack of a strong state library and inadequate public library service in many areas of the state. With a newly strengthened state library and the increase of public and county library systems the demands for this service may diminish.

\section{Nonprofessional-Professional Ratios}

McNeal has suggested raising the nonprofessional to professional ratios in libraries in which this ratio is unusually low as one means of increasing efficiency and lowering total salary costs. ${ }^{9}$ The ratios must be analyzed for each depart-

\footnotetext{
8 Andrew H. Horn, "Introduction," Library Trends, IV $(1955), 119$.

- Archie M. McNeal, "Financial Problems of University Libraries," CRL, XV (1954), 407-10, 420.
} 
ment of a library in terms of the needs and objectives of that particular department because there is a wide variation in these ratios among departments. Table 4 gives the median, high and low ratios for selected library departments. These ratios were computed on the basis of full-time staff members. Because of the difficulty of obtaining accurate data, the number of part-time employees was not requested for this study. Average wages spent by staff and salary distribution with that of the libraries in this sample. It would be of value if such comparisons were reported.

The data have been used also to test certain assumptions regarding the relationship of various factors and library staff distribution and costs. Only size of library, student enrollment, and the number of special and professional libraries were correlated with the data, but some

TABLE 4

MEDIANS AND RANGE OF NONPROFESSIONAL-PROFESSIONAL RATIOS AND AVERAGE WAGES ALLOCATED TO SELECTED FUNCTIONS AND DEPARTMENTS IN 16 UNIVERSITY LIBRARIES, 1954-55

\begin{tabular}{l|c|c|c|c}
\hline \hline $\begin{array}{l}\text { Function or } \\
\text { Department }\end{array}$ & $\begin{array}{c}\text { Median } \\
\text { Ratio }\end{array}$ & $\begin{array}{c}\text { High } \\
\text { Ratio }\end{array}$ & $\begin{array}{c}\text { Low } \\
\text { Ratio }\end{array}$ & $\begin{array}{c}\text { Average } \\
\text { Wages }\end{array}$ \\
\cline { 1 - 4 } Acquisitions & 2.33 & 5.00 & .67 & $\$ 4,990$ \\
Cataloging & .85 & 1.67 & .57 & 3,565 \\
Circulation & 2.75 & 5.50 & .33 & 13,315 \\
Reference & .15 & 1.50 & 0 to 1 & 1,734 \\
Special Libraries & 1.14 & 3.40 & .40 & 15,772 \\
Special Collections & .50 & 1 to 0 & 0 to 3 & 2,617 \\
\hline
\end{tabular}

Data are given for full-time staff only. Nonprofessional-professional Ratios were computed by dividing the number of professional employees in to the number of nonprofessional employees. A high ratio indicates a greater number of nonprofessional than professional employees.

each department are included in Table 4 to give an indication of the extent of part-time work in the departments. The differences in ratios among departments would make an invaluable separate study. However, it is suggested that in any future investigation, the total number of part-time employees be obtained and computed into the ratios.

\section{Summary}

The study reported here has been an exploratory attempt to understand the distribution of library service and its cost. The data have practical use to individual libraries in understanding their staff needs, strengths and weaknesses and in long range personnel budget planning. Libraries may wish to compare their own clear-cut results were indicated. However, the number of libraries in the sample is too small to claim that these findings are conclusive. It is felt that many other factors also affect library service costs and that these should be studied. The approach used in this investigation may be useful in future studies. A similar study, or series of studies, of a large sample of libraries over a period of several years or perhaps at regular intervals would be of inestimable value. Future investigations should study the effect of not only size of library and student enrollment on the costs of libraries but of many other variables as well. The samples should include subgroups that consist of a large number of libraries of comparable size, with comparable organizational patterns and other (Continued on page 530) 
modern Europe, are the critical periods for the rise of the great modern European libraries. Here we have the seedbed of our occidental culture.

The essay on French libraries from the Renaissance to the present by Klaiber and Kolb is one of the most valuable sections in the new edition of the Handbuch. There is no other comprehensive history of French libraries, and even the partial treatments are very few. Quite naturally, major emphasis is on the libraries of Paris, but the noble collections of the provinces are not neglected. The final selection, on administration and financing of French libraries, is somewhat less than encouraging; but the larger picture is a brilliant one, for the resources of French libraries for humanistic and historical studies are unparalleled.

The first essay in the second part of volume three, Leyh's study of modern German libraries, is not complete at this writing and deserves an extended review as an independent monograph.-Lawrence $S$. Thompson, University of Kentucky Libraries.

\section{The Distribution and Cost of Library Service}

(Continued from page 482)

differences that may affect service costs.

The response of libraries to the pressures of institutional needs and growth are apparent from these data. Thus, the organization and cost of library service is directly related to the teaching and research program of the university of which the library is a part; indeed it is deter- mined by the demands which students and faculty make upon it. The statistics seem to substantiate our hypotheses; and the suggestion is advanced that statistical analysis of the budgets of a larger sample of libraries should reach conclusions of high practical value in library administration.

\section{Eastern College Librarians Conference}

The 42nd annual Conference of Eastern College Librarians will be held in the Harkness Auditorium, Butler Library, Columbia University, on Saturday, November 24, 1956. The morning session, beginning at 9:45 a.m., will be on the topic, "Staff Participation in Library Management." The afternoon session, starting at 2 p.m., is to be devoted to the topic of "Librarians as Bookmen." Speakers at the morning session will be E. Hugh Behymer and Keyes D. Metcalf; at the afternoon session, Bertha M. Frick, Richard S. Wormser, and Charles B. Shaw. 